〈연구논문(학술)〉

폴리에스터 고강력사를 이용한 요트용 세일의 제조 및 성능분석

손현식 · 심승범 ${ }^{1} \cdot$ 민문홍 $^{\dagger}$

한국염색기술연구소, ${ }^{1}$ 한국섬유개발연구원

\title{
Preparation of Yacht Sail Using High Tenacity Polyester and Its Performance Evaluation
}

\author{
Hyun-Sik Son, Seung-Bum Sim ${ }^{1}$ and Mun-Hong $\operatorname{Min}^{\dagger}$ \\ Korea Dyeing Technology Center, Daegu 703-834, Korea \\ ${ }^{1}$ Korea Textile Development Institute, Daegu 703-712, Korea
}

(Received: November 11, 2011/Revised: December 2, 2011/Accepted: January 17, 2012)

\begin{abstract}
This study surveyed the preparation of $8 \mathrm{oz}$ coated fabric and the physical property of the coated fabric according to the treated condition for the sail yacht. And the coated fabrics were compared with the performance of overseas products for verification. Physical properties of the coated fabric treated with non-yellowing functional polyurethane resin were examined according to the treatment condition such as compression and ageing treatments. Finally, yellowing fastness to light for 60 hours was assessed. Considering the compression condition after coating, good physical property was obtained at $6 \mathrm{kgf} / \mathrm{cm}^{2}$. Also, the performance of yellowing fastness was similar to performance of overseas goods.
\end{abstract}

Keywords: yacht sail, non-yellowing, polyurethane resin, compression, coated fabric

\section{1. 서 론}

우리나라의 경제적 수준이 높아지면서 주 5일 근 무제의 도입과 함께 주말 여가시간을 레저 스포츠 와 함께하는 인구가 증가하고 있으며, 그 중에서도 미국, 유럽 대양주 등 선진국에서 이미 대중화되어 있는 해양스포츠 분야에 대한 관심이 국내에서도 차츰 높아지고 있다. 특히 해양 레저 스포츠의 꽃 이라고 할 수 있는 세일링 요트에 대한 수요가 높 아짐에 따라 관련 요트 개발에 대한 연구가 최근 활발하게 진행되고 있다. 세일링 요트(sailing yacht) 는 일반 선박과는 달리 세일에 의해 추진력을 얻는 방식으로써, 세일의 성능이 좋을수록 빠른 속도를 낼 뿐만 아니라 세일에 의해 발생하는 힘은 선체 자세를 바꾸어주는 등의 전반적 항해 성능에도 큰 영향을 미치고, 특히 세일요트 경주와 같이 속도 위주로 항해하는 경우에는 선수의 항해 능력뿐만 아니라 바람의 저항을 최대한 활용하여 요트의 추 진력으로 전환시키는 세일의 성능이 매우 중요하므 로, 세일의 성능이 요트의 성능과 밀접한 관련이
있다 ${ }^{1,2)}$.

국내에서 사용되고 있는 레저 및 경기용 세일 원 단은 세일 제조회사 등을 통해 해외에서 직수입된 제품이 대부분이며, 세일 제조회사들은 수입된 원 단을 이용하여 요트 선주들이 보유하고 있는 요트 의 종류나 규격에 적합하도록 세일을 설계 - 제작하 는 주문제작 방식으로 판매하거나, 선주들이 해외 세일 제조회사에 직접 주문하여 완제품 형태로 국 내에 수입되고 있는 실정이다.

해외에서 개발 및 생산되고 있는 직물 형태의 메 인 및 지브 세일용 소재는 주로 폴리에스터 고강력 사가 사용되고 있으며, 이를 이용하여 고밀도 제직, 전처리, 코팅 및 후가공을 통해 세일용 원단을 제 조하고 있다. 직물 세일의 주요한 필수 요구 성능 은 우수한 내후성과 기밀성, 높은 강도와 낮은 신 축성, 방향성 최소화 및 경량성 등이다. 즉, 세일은 주로 해양에서 사용되기 때문에 바닷물, 태양광, 기 후 등에 대한 내후성이 요구되고, 요트의 추진력을 높이기 위해 세일 내 섬유사이의 공극을 최소화하여 원단의 기밀성을 높여 섬유사이로 투과되는 공기의

${ }^{\dagger}$ Corresponding author. Tel.: +82-53-350-3921; Fax.: +82-53-350-3927; e-mail: hsson95@dyetec.or.kr

(c)2012 The Korean Society of Dyers and Finishers 1229-0033/2012-03/54-61 
양을 최소화해야 하며, 세일을 장시간 사용할 경우, 풍력에 의한 원단의 늘어짐과 변형을 최소화할 수 있도록 높은 강도, 신축성 및 방향성 최소화, 치수 안정성 향상 등이 요구되고 있다.

해외 세일용 원단 제조업체에서는 상기에서 언급 한 주요 요구 성능을 만족시키기 위하여, 세일의 공기투과성을 최소화하고 제품의 내구성을 높일 수 있도록 제직된 고밀도 직물에 대해 UV차단성, 무 황변성 등의 성능을 갖는 기능성 수지를 이용하여 원단표면에 수지의 잔류를 최소화함으로써 초크 마 크(chalk mark) 발생을 억제하고, 원단 내부로 수지 의 침투 균일성을 향상시켜 표면 촉감, 물성 및 성 능 등이 향상될 수 있도록 습식코팅(dip/squeeze) 가 공이나 건식코팅 가공을 실시한 후, 코팅된 제품의 치수안정과 원단기밀성 향상을 위해 큐어링 가공, 캘린더가공 및 기타 마무리 가공 등의 후가공을 통 해 세일 소재를 생산하고 있다 ${ }^{3-9)}$.

국내 세일과 관련된 기존의 연구는 완제품 형태 의 세일에 대한 풍동 실험 등 요트의 추진력을 향 상시키기 위한 세일의 유동학적 수치해석이나 공력 특성을 추정하는 등의 연구가 대부분이며, 세일 제 조와 제품의 물성과 성능 분석 등을 통한 제품 개 발과 관련된 연구는 전무한 실정이다 ${ }^{10-12)}$. 그 이유 는 최근까지 국내에서는 해양 스포츠의 활성화가 이루어지지 않아 세일링 요트에 대한 수요가 낮은 점에서 비롯되었다고 볼 수 있으며, 또한 상기에서 언급한 바와 같이 요트용 세일이 전량 수입에 의존 하고 있고, 국내 기술로 제품화된 사례가 없어 세 일 개발과 관련된 전용 수지의 개발, 코팅 등의 후 가공과 관련된 기술에 대한 연구가 지속적으로 이 루어지지 못한 것으로 사료된다.

본 연구에서는 현재 전량 수입되어 세일링 요트 에 사용되는 세일을 개발하기 위해, 폴리에스터 고 강력사를 사용하여 고밀도 직물을 제작하였고, 코 팅가공을 위한 수지는 에스테르형 폴리올에 화학적 반응이 적고 광안정성이 우수한 지방족 이소시아네 이트 화합물을 함유한 폴리우레탄 수지를 사용하였 으며, 코팅가공은 기존의 dip/squeeze 방식의 코팅 효과를 일반 건식 코팅 방식에 적용할 수 있도록 하기 위해, 개조된 건식 나이프 타입의 코팅기로 원
단에 수지를 1 회 도포한 후 수지가 원단 내부로 균 일하게 침투될 수 있도록 개발한 압착설비로 squeezing 한 다음 큐어링을 실시하였다. 또한 가공된 원단 내 부에 미 경화된 수지의 완전한 경화를 위해 코팅원 단에 대해 건열 에이징 가공을 실시하였다. 기존 폴 리우레탄 수지의 경우에는 코팅 후 큐어링을 통해 단시간에 완전 경화가 이루어지지만, 본 연구에 적 용한 폴리우레탄 수지와 가교제의 조성물 중에 존재 하는 IPDI(Isophorone Diisocyanate)는 광안정성은 우수 하나 현재 상용화된 이소시아네이트 화합물 중 가 장 반응성이 느리고 ${ }^{13,14)}$, 또한 코팅 가공을 위한 폴 리우레탄 수지의 배합 시 기존 코팅가공 배합조건 보다 가교제 함량을 증가시켰기 때문에 가공 후 원 단 내에 존재하는 미 반응된 수지의 완전한 경화와 경화 시간을 단축시킬 목적으로 추가의 건열 에이 징 가공을 수행하였다.

그러나 상기의 제조 공정 중에서 압착조건과 에 이징 처리 조건에 따라 세일의 물성과 성능의 차이 가 발생하는 것을 확인함에 따라 압착 및 에이징 가공 조건 별로 세일의 물성과 성능에 대한 분석을 통해 성능을 향상 시킬 수 있는 최적의 가공 조건 의 도출이 요구되었다. 이에 본 연구에서는 코팅 한 시료에 대해 압착가공 시 압력 조건을 $5 \mathrm{kgf} / \mathrm{cm}^{2}$, $6 \mathrm{kgf} / \mathrm{cm}^{2}$ 및 $7 \mathrm{kgf} / \mathrm{cm}^{2}$ 로 변화시켜 원단의 물성을 측 정하였으며, 압착 가공을 실시한 시료에 대해 큐어 링 가공 후 $85^{\circ} \mathrm{C}$ 챔버 내에서 12,24 및 36 시간 동 안 에이징 가공을 실시하여 물성변화를 관찰함으로 써, 최적의 코팅 및 후가공 조건을 확립하고자 하 였다. 또한 처리된 원단의 황변견뢰도, 광 조사 후 인장 강-신도의 저하여부, SEM을 통해 표면 및 단 면을 관찰하여 수지의 원단표면 잔류 여부 및 내부 침투 균일성 등을 확인함으로써 세일의 성능 적합 성 여부를 확인하였다.

\section{2. 실 험}

\section{1 시험포의 전처리}

본 연구에서는 (주)코오롱에서 생산되고 있는 폴 리에스터 고강력사를 사용하여 고밀도 평직으로 제 직한 원단을 시험포로 이용하였다.

Table 1. Specification of base material and fabric for sail cloth

\begin{tabular}{|c|c|c|c|c|}
\hline Sample & Weaving Spec. & Composition & $\begin{array}{c}\text { Density } \\
(\text { ends/in } \times \text { pick/in }) \\
(\mathrm{Wp} \times \mathrm{Wf})\end{array}$ & $\begin{array}{l}\text { Weight } \\
\text { (oz) }\end{array}$ \\
\hline $\begin{array}{l}\text { High Tenacity } \\
\text { Polyester }\end{array}$ & $\begin{array}{l}\text { Wp - P/F SDY 510d/96f } \\
\text { Wf - P/F SDY } 750 d / 144 f\end{array}$ & $\begin{array}{c}\text { Polyester } \\
100 \%\end{array}$ & $75 \times 32$ & 7.9 \\
\hline
\end{tabular}


제직한 시료의 호발, 정련을 위해 Nicca Korea의 합성섬유용 정련제인 Sclean $\mathrm{AN}$ 과 호발제인 Sclean 606 및 $50 \%$ 가성소다를 사용하여 $98^{\circ} \mathrm{C}$ 에서 40 분간 전처리를 실시하였다. Table 1에는 시험포로 사용 한 원사 및 직물의 사양을 나타내었다.

\section{2 코팅 수지 배합 및 코팅 조건 설정}

시료에 대한 코팅가공을 위해, Table 2와 같은 조건으로 수지 배합을 실시하였다. 수지는 (주)동아 화학의 diethylene glycol, ethylene glycol, adipic acid로 구성된 에스테르형 polyol을 isophoron diisocyanate 로 반응시킨 후 ethylene glycol과 diethylene glycol을 반응시킨 폴리우레탄 수지를 사용하였다. 폴리우레 탄 수지의 배합을 위해, 점도 조절용 용제로는 (주) 풍천산업의 methyl ethyl ketone(MEK)을 사용하였으 며, 수지의 경화용으로는 (주)동아화학에서 제조한 trimethyl propanol과 isophoron diisocyanate을 반응시 킨 가교제를 사용하였다.

배합된 코팅 수지를 이용하여 Table 3에 나타낸 바와 같은 조건으로 코팅가공을 실시하였다. 코팅 시 $3 \mathrm{~mm}$ 나이프를 이용하여 플롯(float) 방식으로 도포량 $11 \mathrm{~g} / \mathrm{m}^{2}$ 이 될 수 있도록 단면 코팅을 실시하였으며, 코팅 후 수지가 시료 표면에 잔류하지 않고 내부로 균일하게 침투되게 하기 위해 압착시스템을 이용하 여 압착한 후 $150^{\circ} \mathrm{C}$ 열풍 챔버 내에서 1.5 분간 건조 하였다. 압착 가공 시 수지가 시료 표면에 잔류되는 것 을 최소화하고, 시료 내부로 균일하게 침투되는 조건 을 확립하기 위해 압착압력을 $5 \mathrm{kgf} / \mathrm{cm}^{2}, 6 \mathrm{kgf} / \mathrm{cm}^{2}$ 및
$7 \mathrm{kgf} / \mathrm{cm}^{2}$ 로 변화시켜 실험을 실시하였다. 또한 코팅 가공, 압착가공 및 큐어링 가공을 실시한 시료에 대 해 시료 내부로 침투한 수지가 완전히 경화될 수 있도록 하기 위해 건열 에이징 가공을 실시하였으 며, 최적의 에이징 처리 조건을 확립하기 위해 $85^{\circ} \mathrm{C}$ 로 유지되는 챔버 내에서 12,24 및 36시간으로 처 리시간을 달리하여 실험을 실시하였다.

\section{3 물성측정}

요트용 세일의 국산화를 위해, 개발된 코팅 및 후 가공 공정 중 코팅 후 압착조건 $\left(5 \mathrm{kgf} / \mathrm{cm}^{2}, 6 \mathrm{kgf} / \mathrm{cm}^{2}\right.$ 및 $\left.7 \mathrm{kgf} / \mathrm{cm}^{2}\right)$ 을 달리하여 시료의 물성의 변화를 관 찰하고, 시료 내 수지의 완전경화를 위한 에이징 처리 조건(12, 24 및 36시간)에 따른 시료의 물성변 화를 관찰하였다, 이때 물성 테스트는 $\mathrm{KS} \mathrm{K} 0521$ (스트립법)에 의거하여 인장 강-신도를 측정하였다.

세일 소재는 주로 해양에서 사용되기 때문에 태양 광에 의한 취화가 반드시 수반된다. 광 조사에 의한 원단 취화의 발생정도를 관찰하기 위해, 제작이 완 료된 코팅시료에 대해 ISO 105-B02: 1994(Xenon-Arc-Lamp Black Panel, Temperature $60 \pm 3^{\circ} \mathrm{C}$ ) 규정에 의거하여

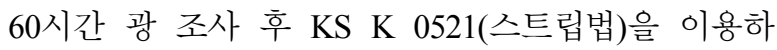
여 강도 및 신도를 측정하여 광 조사 전후의 시료에 대한 강-신도 변화를 비교하였다. 또한 시료의 내황 변 성능을 관찰하기 위해 ISO 105-B02: 1994 및 ISO 105-X18: 2007법에 의거하여 황변 견뢰도 테스트를 실시하였으며, 코팅원단의 수지도포 상태 및 원단 내 침투여부를 SEM(Zeo, Japan)으로 관찰하였다.

Table 2. Formulation of coating resin

\begin{tabular}{cc}
\hline Ingredient & Mixing ratio [PHR] \\
\hline Polyurethane resin & 100 \\
Solvent (MEK) & 3 \\
Cross linking agent (BCL/IP) & 7 \\
\hline
\end{tabular}

Table 3. Treatment condition of coating and finishing process

\begin{tabular}{ccc}
\hline & Process & Condition \\
\hline \multirow{2}{*}{ Coating } & Coating type & Floating type \\
& Knife type & $3.0 \mathrm{~mm}$ \\
& Heat treatment & $150^{\circ} \mathrm{C} \times 1.5 \mathrm{~min}$. \\
\hline \multirow{2}{*}{ Compression } & Mangle pressure & $5 \mathrm{kgf} / \mathrm{cm}^{2}, 6 \mathrm{kgf} / \mathrm{cm}^{2}, 7 \mathrm{kgf} / \mathrm{cm}^{2}$ \\
\hline \multirow{2}{*}{ Ageing } & Chamber temperature & $85^{\circ} \mathrm{C}$ \\
& Treatment time & $12 \mathrm{hour}, 24 \mathrm{hour}, 36 \mathrm{hour}$ \\
\hline
\end{tabular}


또한, 개발한 코팅직물의 물성과 성능이 해외제 품의 성능에 부합되는지에 대한 여부를 확인하기 위해 해외 8oz급 세일(Ocean-755, Bainbridge International Co. Ltd.)의 물성 및 성능과 비교분석하였다.

\section{3. 결과 및 고찰}

\section{1 코팅 직물의 압착 조건에 따른 물성변화}

세일의 물리적 특성과 관련된 주요 성능 지표 중 의 하나는 위사 및 대각선(bias) 방향의 강-신도 특 성이다. 즉, 바람에 대한 세일의 저항 성능에 의해 요트의 추진성능이 좌우되기 때문에 세일의 바람에 대한 저항성을 높이기 위해서는 원단의 강도가 높 고 특히, 신도가 낮아 치수안정성이 우수한 특성이 발현되어야 한다.

Fig. 1은 시료에 대해 코팅가공을 실시한 후 압 착시스템을 이용하여 압력 $5 \mathrm{kgf} / \mathrm{cm}^{2}, 6 \mathrm{kgf} / \mathrm{cm}^{2}$ 및 $7 \mathrm{kgf} / \mathrm{cm}^{2}$ 의 조건으로 처리한 시료에 대한 강도와 신 도를 나타낸 그래프이다.

위사 및 대각선 방향에 대한 강도를 측정한 결과, $7 \mathrm{kgf} / \mathrm{cm}^{2}$ 의 압력으로 처리한 시료는 각각 $1,900 \mathrm{~N}$ 및 $1,100 \mathrm{~N}$ 으로써, $5 \mathrm{kgf} / \mathrm{cm}^{2}$ 의 압력으로 압착한 시료의 강도인 $1,700 \mathrm{~N}$ 과 $1,000 \mathrm{~N}, 6 \mathrm{kgf} / \mathrm{cm}^{2}$ 의 압력으로 압착 한 시료의 강도인 $1,700 \mathrm{~N}$ 및 $900 \mathrm{~N}$ 보다 높은 값을 나타내었다. 또한 위사 및 대각선 방향 신도를 측정 한 결과, $6 \mathrm{kgf} / \mathrm{cm}^{2}$ 의 압력으로 처리한 시료의 신도의 경우가 $24.2 \%$ 및 $38.8 \%$ 로 가장 낮게 나타났으며,

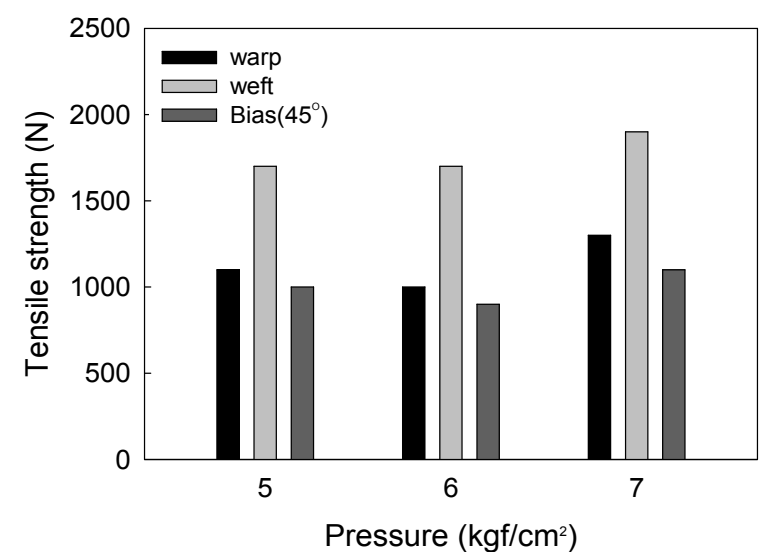

(a) Strength
$7 \mathrm{kgf} / \mathrm{cm}^{2}$ 의 압력으로 처리한 시료의 신도가 $26.1 \%$ 및 $41.4 \%$ 로 가장 높은 것으로 나타났다.

Table 4는 코팅된 시료에 가해지는 압력조건에 따 른 두께 및 중량의 변화를 나타낸 결과이다. 표에서 보는 바와 같이, 코팅된 시료에 가해지는 압력이 증 가할수록 중량은 감소하는 경향을 나타내는 것을 볼 수 있다. 압착하는 압력이 증가할수록 중량이 감소되 는 주요 원인은 코팅 시 시료에 도포된 수지가 압착 부 맹글의 강한 squeeze 작용에 의해 원단 표면으로 빠져나와 압착부에 잔류하게 됨으로써 압착부를 지 난 원단은 수지가 빠져나간 만큼 원단 중량이 감소한 것 으로 판단된다. 이러한 과도한 중량의 감소는 세일의 치 수안정성과 성능에 영향을 미치게 되므로 $7 \mathrm{kgf} / \mathrm{cm}^{2}$ 의 처 리조건은 바람직하지 않은 것으로 판단된다.

종합적인 결과로 볼 때, $7 \mathrm{kgf} / \mathrm{cm}^{2}$ 의 처리조건은 다 른 처리 조건 보다 위사 및 대각선 방향의 신도차가 최대 $2 \%$ 및 $2.6 \%$ 정도의 차이를 나타내고, 도포된 수지가 압착에 의해 $4.28 \mathrm{~g} / \mathrm{m}^{2}$ 정도가 감소됨에 따라, 수지 감소에 의한 치수안정성 신도증가로 시료의 치 수안정성에 영향을 미칠 가능성이 있어 제외하는 것이 바람직하다고 판단되며, 코팅 후 시료에 대한 최적 압 착조건은 $6 \mathrm{kgf} / \mathrm{cm}^{2}$ 이하의 압력 조건에서 처리하는 것 이 세일 소재로의 적용에 적합하다고 판단된다.

\section{2 에이징 처리 시간이 코팅 직물의 물성에} 미치는 영향

건열 에이징 가공은 코팅 후에 시료 내에 잔류하고 있는 미 반응 수지의 완전경화를 통해 시료의 치수

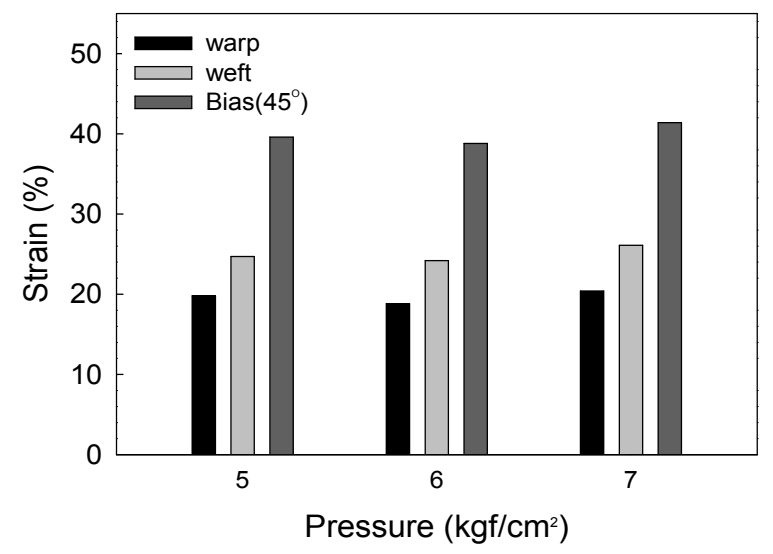

(b) Strain

Fig. 1. Physical properties of the coated samples according to the compression condition.

Table 4. Weight and thickness of the coated samples according to the compression condition

\begin{tabular}{cccc}
\hline & $5 \mathrm{kgf} / \mathrm{cm}^{2}$ & $6 \mathrm{kgf} / \mathrm{cm}^{2}$ & $7 \mathrm{kgf} / \mathrm{cm}^{2}$ \\
\hline Weight $\left(\mathrm{g} / \mathrm{m}^{2}\right)$ & 355.24 & 354.20 & 350.96 \\
Thickness $(\mathrm{mm})$ & 0.24 & 0.24 & 0.24 \\
\hline
\end{tabular}


안정성, 표면감 등을 향상시키기 위해 적용된 공정 으로써, 반응성이 느린 수지 및 가교제의 조성물 중 의 하나인 IPDI(Isophorone Diisocyanate)의 사용과 코 팅제 배합 시 충분한 반응을 통한 수지의 경화가 완료될 수 있도록 하기 위해 가교제 투입량을 증가 시켰기 때문에 기존 코팅 및 큐어링 공정에서 수지 의 완전한 경화가 이루어지지 않는다는 것을 확인하 여, 수지의 완전한 경화와 경화 반응시간 단축 및 생 산성 향상을 위해 건열 에이징 가공을 추가하여 공 정을 설계하였다. 즉, 코팅 가공 후 에이징 가공을 실시하여 수지가 완전히 경화됨으로써 원단의 신장 성을 최소화하고 치수안정성을 높여 바람에 대한 저 항력과 내구성을 향상시키고, 장시간 사용 후에도 원 단의 변형이 최소화될 수 있도록 하였다.

본 연구에서는 에이징 시 경화 반응이 종료되는 시점을 파악하고 치수안정성이 향상되는 조건을 확 보하기 위해, $11 \mathrm{~g} / \mathrm{m}^{2}$ 으로 도포한 코팅직물에 대해 $6 \mathrm{kgf} / \mathrm{cm}^{2}$ 으로 압착처리를 실시하고, $180^{\circ} \mathrm{C}$ 에서 1.5 분간 큐어링 처리한 시료에 대해 $85^{\circ} \mathrm{C}$ 챔버 내에서 12 시간, 24 시간 및 36 시간의 조건으로 에이징 처리 하여 실험을 진행하였다.

Fig. 2 는 $85^{\circ} \mathrm{C}$ 의 챔버 온도 내에서 각각 12,24 , 36 시간 에이징 처리한 시료의 물성변화에 대한 결 과이다. 에이징 시간이 12 시간에서 36 시간으로 길 어질수록 위사 방향의 강도는 24시간 에이징 처리 한 경우가 $1,960 \mathrm{~N}$ 으로 가장 높게 나타났고, 신도의 경우에는 12 시간 에이징 시의 $24.6 \%$ 에 비해 24 및 36 시간 에이징 처리한 시료의 신도가 $24.2 \%$ 로 $0.4 \%$ 감소하여 치수안정성이 다소 개선됨을 알 수 있다. 특히, 대각선 방향의 강-신도 변화를 살펴보면 12시 간 동안 에이징 처리한 시료의 강-신도가 각각 $911 \mathrm{~N}$ 및 $54.6 \%$ 비해, 24시간 처리한 시료의 강.신 도 값은 $722 \mathrm{~N}$ 및 $48.6 \%$ 에 비해 강-신도 차가 $119 \mathrm{~N}$, 신도 $6 \%$ 만큼 급격히 감소함을 알 수 있었다.

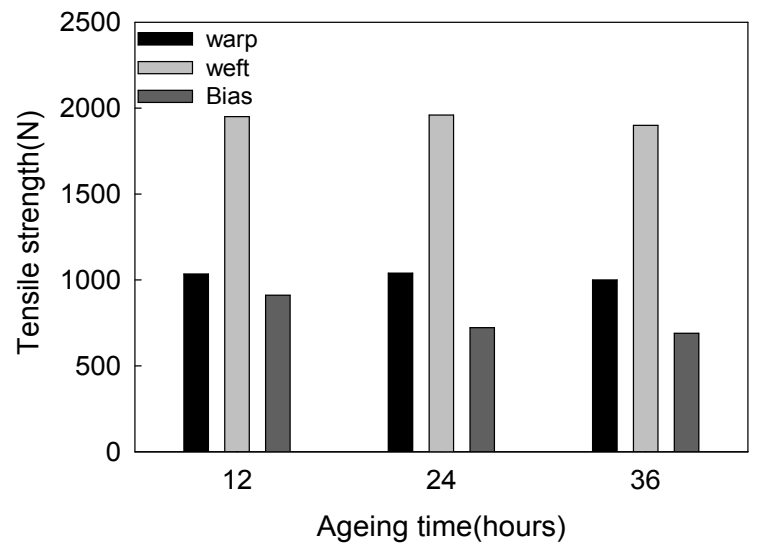

(a) Strength
위사방향 및 대각선방향의 강-신도 값을 고려해 볼 때, 24시간 이상 에이징 처리한 시료의 경우가 12 시간 처리한 시료의 강도보다 다소 감소하는 경향을 나타내고 있으나 시료의 치수안정성 측면 을 고려할 때, 24시간 이상 에이징 처리한 시료의 신도 감소가 크게 나타났기 때문에 세일 특성에 유 리하다고 판단된다.

3.3 광 조사에 따른 시료의 강도변화 및 황변 견뢰도 분석

해양에서 사용되는 요트용 세일의 특성 상 태양 광에 의한 소재의 강도 취화와 제품의 견뢰도 저하 가 필수적으로 수반된다. Fig. 3은 60시간 광 조사 처리를 한 시료와 미처리 시료에 대한 인장강도에 대한 결과를 나타내었다. 실험결과, 미처리 시료의 경위사 방향 인장강도는 $1,040 \mathrm{~N}, 1,960 \mathrm{~N}$ 이며, 60 시 간 광 조사 후 측정한 시료의 인장강도는 각각 $1,000 \mathrm{~N}$ 및 $1,760 \mathrm{~N}$ 으로 나타났다. 미처리 시료 대비 경사방 향으로는 약 $4 \%$, 위사방향으로는 약 $10.2 \%$ 의 강도 취화가 발생한 것을 알 수 있었다.

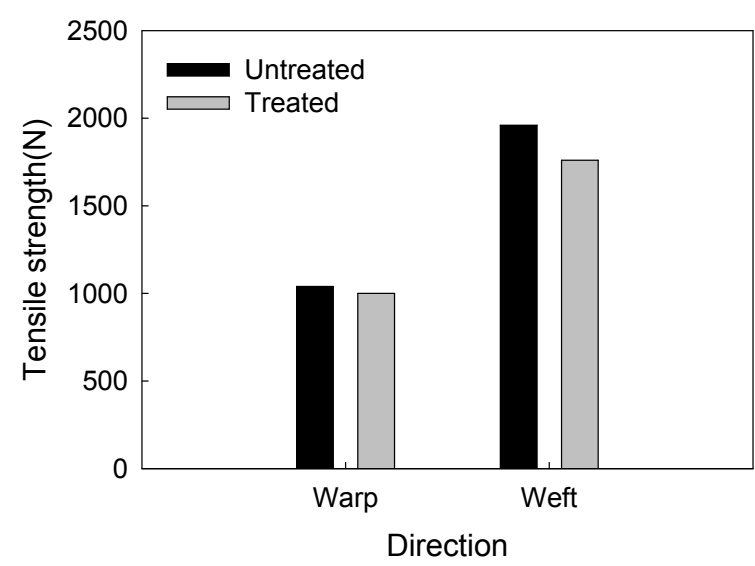

Fig. 3. Strength of the coated samples according to daylight exposure for 60 hours.

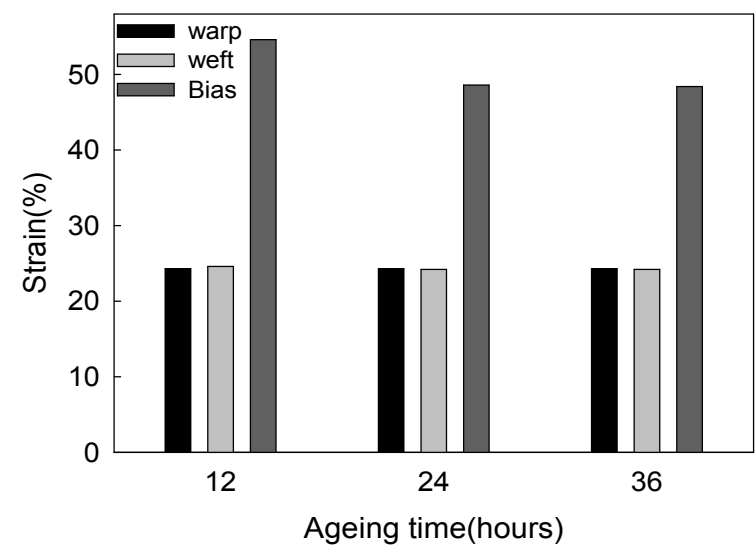

(b) Strain

Fig. 2. Physical properties of the coated samples according to the ageing condition. 
Table 5는 코팅 시료의 60 시간 동안 광 조사 후 측정한 황변견뢰도에 대한 결과를 나타내었다. 시료 에 대한 황변견뢰도는 3 4급으로 나타나, 해외 제 품 황변 견뢰도 4 5급에 다소 미치지 못하는 것으 로 나타났다. 황변성은 섬유제품의 문제이기 보다 수지 등의 가공제가 장시간 동안 폐놀계 화합물이 나 산화질소 $\left(\mathrm{NO}_{\mathrm{x}}\right)$ 에 노출되어 반응함으로써 나타나 는 결과이므로, 폐놀계 화합물이나 산화질소에 반 응하지 않는 무황변 타입 수지의 선정을 통해 황변 견뢰도를 향상시킬 수 있을 것으로 판단된다.

\section{4 해외 제품과의 성능 비교}

원단에 수지를 $11 \mathrm{~g} / \mathrm{m}^{2}$ 로 도포하여 코팅을 실시하 고 압력 $6 \mathrm{kgf} / \mathrm{cm}^{2}$ 의 조건으로 압착가공을 실시한 후, $180^{\circ} \mathrm{C}$ 에서 큐어링 가공 및 $85^{\circ} \mathrm{C}$ 조건 하에서 24시간 에이징 처리하여 제조된 시료의 물성을 측 정하여 해외 선진제품의 실측치와 비교한 결과를 Table 6에 나타내었다. 해외 제품과 비교하여 위사 방향 및 대각선방향의 인장강도는 $1,800 \mathrm{~N}$ 및 $722 \mathrm{~N}$ 으로 해외 제품보다 높게 나타났으나 신도는 위사 방향 $26.4 \%$ 로 해외제품 $25.8 \%$ 에 비해 다소 성능이
떨어지는 것을 알 수 있었다. 대각선방향 인장강도 는 해외제품의 $690 \mathrm{~N}$ 에 비해 $722 \mathrm{~N}$ 으로 높게 나타났 으며, 신도의 경우에도 $42 \%$ 로써, 해외제품의 $44 \%$ 보다 성능이 우수함을 알 수 있었다. 종합적으로 볼 때, 중량이 다소 큰 경향은 있으나 강-신도 측면에 서 해외 제품의 물성치에 부합됨을 알 수 있었다.

Table 7은 제조된 시료와 해외제품에 대한 단면 형상을 확인하기 위해 $\mathrm{SEM}$ 촬영 결과를 나타내었 다. 단면에서 보는 바와 같이, 제조된 시료의 경우 에는 코팅가공을 통해 수지가 원단내부로 침투되어 섬유표면을 감싸고 있는 것을 확인할 수 있으나 섬 유 간 집속성이 좋지 않고 원단 표면에서 수지가 해외 제품에 비해 얇은 막 형태로 잔류되어 있는 것을 알 수 있다. 반면에 해외제품의 경우에는 수 지가 원단 내부로 균일하게 침투되어 있는 것을 확 인할 수 있으며, 표면의 경우에도 수지의 잔류가 거의 없는 것을 알 수 있다.

해외 제품의 경우에는 물성에 비해 위사밀도가 많고 원단 내부 섬유 간 집속성이 우수하고, 원단표 면에 잔류하는 수지가 거의 없어 우수한 표면터치

Table 5. Fastness of the coated samples and Ocean-755 according to daylight exposure for 60 hours

\begin{tabular}{cc}
\hline Classification & Yellowing fastness (grade) \\
\hline Test sample & $3 \sim 4$ \\
Ocean-755 & $4 \sim 5$ \\
\hline
\end{tabular}

Table 6. The characteristic comparison of test sample and Ocean-755

\begin{tabular}{|c|c|c|c|c|c|c|c|}
\hline \multirow[b]{2}{*}{ Classification } & \multirow[b]{2}{*}{$\begin{array}{c}\text { Denier } \\
(\mathrm{Wp} \times \mathrm{Wf})\end{array}$} & \multirow{2}{*}{$\begin{array}{c}\text { Weft } \\
\text { density } \\
\text { (ea) }\end{array}$} & \multicolumn{2}{|c|}{ Weft direction } & \multicolumn{2}{|c|}{ Bias direction } & \multirow{2}{*}{$\begin{array}{l}\text { Weight } \\
\left(\mathrm{g} / \mathrm{m}^{2}\right)\end{array}$} \\
\hline & & & $\begin{array}{l}\text { Strength } \\
(\mathrm{N})\end{array}$ & $\begin{array}{c}\text { Strain } \\
(\%)\end{array}$ & $\begin{array}{l}\text { Strength } \\
(\mathrm{N})\end{array}$ & $\begin{array}{c}\text { Strain } \\
(\%)\end{array}$ & \\
\hline Test sample & $510 \mathrm{~d} \times 750 \mathrm{~d}$ & 32 & 1,800 & 26.4 & 722 & 42 & 340 \\
\hline Ocean-755 & $450 \mathrm{~d} \times 850 \mathrm{~d}$ & 40 & 1,700 & 25.8 & 690 & 44 & 329 \\
\hline
\end{tabular}

Table 7. SEM photograph of test sample and Ocean-755

\begin{tabular}{|c|c|c|c|}
\hline Classification & Warp direction & $\mathrm{Wet}$ & ction \\
\hline Test sample & & & \\
\hline Ocean-755 & & & \\
\hline
\end{tabular}


와 부드러운 굴곡성을 가지고 있으나 제조된 시료 의 경우에는 수지가 원단 내부로 완전히 침투되지 못하고 표면에 잔류되어 있으며, 섬유 간 집속성이 없는 상태에서 수지가 경화되어 시료가 뺏뺏하여 굴곡성이 좋지 못한 결과를 나타내었다. 이러한 특 성은 세일을 단기간 사용할 경우에는 바람의 저항 을 크게 받아 추진력 향상에 도움이 될 수 있으나, 장기간 사용 시에는 내구성에 불리하게 작용될 것 으로 판단된다.

\section{4. 결 론}

우수한 물성, 견뢰도 및 내구성능을 발현하는 요 트용 세일의 국산화와 가공 공정기술 개발에 대한 연구를 수행하기 위해, 폴리에스터 고강력사로 제 직한 직물에 대해 코팅, 압착가공 및 에이징 가공 을 조건별로 실시한 세일 소재의 물성 및 성능분석 을 실시하고 해외 제품과의 성능 부합 여부를 검토 한 결과 다음과 같은 결론을 얻었다.

1. 제조한 원단에 대해 수지 도포량이 $11 \mathrm{~g} / \mathrm{cm}^{2}$ 이 되 도록 코팅을 실시한 후 압착시스템을 이용하여 $5 \mathrm{kgf} / \mathrm{cm}^{2}, 6 \mathrm{kgf} / \mathrm{cm}^{2}, 7 \mathrm{kgf} / \mathrm{cm}^{2}$ 의 압력 조건으로 압 착 처리한 시료에 대한 인장 강도 및 신도를 측정 한 결과, 압력을 $6 \mathrm{kgf} / \mathrm{cm}^{2}$ 로 압착 가공한 시료에 대한 위사 및 대각선 방향의 신도가 각각 $18.8 \%$ 및 $24.2 \%$ 로 가장 낮게 나타났다. 강도의 경우에는 $6 \mathrm{kgf} / \mathrm{cm}^{2}$ 압착 조건이 타 조건에 비해 다소 낮은 경향이 있으나 세일의 내구성에 가장 큰 영향을 미 치는 치수안정성을 고려한다면 $6 \mathrm{kgf} / \mathrm{cm}^{2}$ 조건이 가 장 부합됨을 알 수 있었다.

2. 시료 내에 침투한 수지의 완전 경화를 통한 치 수 안정성을 확보하기 위해, 시료의 $85^{\circ} \mathrm{C}$ 챔버 내 에서 12 시간, 24 시간, 36 시간의 조건으로 에이징 처리한 시료에 대한 물성변화를 측정한 결과, 24 시간 이상 에이징 처리한 시료의 위사방향의 강. 신도가 $1,960 \mathrm{~N}$ 및 $24.2 \%$ 로 강도는 가장 높았으 며 신도는 가장 낮게 나타나 치수안정성이 가장 우수함을 알 수 있었다. 대각선 방향의 강-신도 또한 12 시간 처리한 강-신도 값인 $911 \mathrm{~N}$ 및 $54.6 \%$ 에 비해 24시간 에이징 처리한 시료의 인 장 강-신도 값이 $722 \mathrm{~N}$ 및 $48.6 \%$ 로 감소하여 강 도는 다소 감소하는 경향을 나타내어 치수안정 성에서는 다소 유리하나 강도가 급격히 감소하 는 경향을 보임에 따라 이를 보안하기 위한 고 밀도 제직 조건을 개선할 필요가 있다고 사료된 다. 36 시간 에이징 처리한 시료의 경우에는 24 시 간 에이징 처리한 시료에 비해 강도가 낮고 신 도는 동일한 결과가 나타나 최적 에이징 시간은
24시간임을 알 수 있었다.

3. $6 \mathrm{kgf} / \mathrm{cm}^{2}$ 의 압착가공과 $85^{\circ} \mathrm{C}$ 조건에서 24 시간 에 이징 가공을 통해 제조된 시료에 대해, 태양광에 장시간 노출됨에 따른 강도의 변화와 장시간 동 안 폐놀계 화합물이나 산화질소 $\left(\mathrm{No}_{\mathrm{x}}\right)$ 에 노출되어 나타나는 시료의 황변 견뢰도를 측정한 결과, 60 시간 광조사한 시료가 미처리 시료에 비해 경사 방향으로는 $4 \%$, 위사방향으로는 $10.2 \%$ 의 강도취 화가 발생하였으며, 황변견뢰도는 3 4급으로 나 타났다. 동일한 조건으로 실험한 해외 제품의 경 우에는 광 조사 후 경위사 방향의 강도 취화가 발생하지 않았고 견뢰도 또한 4 5급으로 나타남 에 따라, 제조한 코팅시료에 대한 위사방향의 내 구성능을 개선하기 위한 제직조건 개선과 무황변 타입의 수지합성에 관한 추가 연구가 필요한 것 으로 사료된다.

4. 개발한 시료와 해외제품간의 물성 및 성능을 종 합적으로 검토한 결과, 위사방향의 신도와 중량 은 다소 낮은 값을 나타냈으나, 위사 및 대각선 방향의 강도와 대각선 방향 신도는 높게 나타나 해외제품의 물성에 유사한 수준임을 알 수 있었 다. 그러나 장시간 광 조사 후의 강도 취화와 황 변성능, 원단 내부로의 수지 침투성이 다소 부족 하여, 이를 개선하기 위한 추가의 연구가 필요한 것으로 판단된다.

$$
\text { 감사의 글 }
$$

본 연구는 지식경제부 슈퍼소재융합제품화기술개 발사업의 연구비 지원으로 수행되었음.

\section{참고문헌}

1. H. R. Chi, W. J. Kim and J. H. Kim, Turbulent Flow Calculation around Yacht Sails, J. of the Society of Naval Architects of Korea, 44(2), 6473(2007).

2. H. B. Lee, S. H. Rhee and J. H. Yoo, Analysis of a Two-Dimensional Section of Deforming Yacht Sails, J. of the Society of Naval Architects of Korea, 48(4), 308-316(2011).

3. S. Y. Yang, H. A. Kim and S. J. Kim, The Synthesis of One-step Type Hydrophilic Non-porous Polyurethane Resin and the Physical Property of its Coated Fabric for the Garment, Textile Coloration and Finishing(J. of Korean Soc. Dyers \& Finishers), 23(2), 131-139(2011)

4. J. H. Yang, J. W. Jeon, J. H. Yeum, D. H. Kim, K. S. Oh and N. S. Yoon, Synthesis and Appli- 
cation for Hydrophilic Polyurethane of Nonswelling Type, Textile Coloration and Finishing(J. of Korean Soc. Dyers \& Finishers), 23(2), 118130(2011).

5. S. Krishnan, Thermoplastic Polyurethane for Coated Fabrics, J. of Coated Fabrics, 22, 150-160(1992).

6. Y. Tetsuya, T. Sikeru, D. Katsutosi, Korea Pat. 1993-7000669(1993).

7. D. Akira, O. Machiko, M. Hiroyuki, Korea Pat. 2010-7004197(2010).

8. J. H. Yang, S. Y. Yang, M. O. Lee, S. S. Kim, H. S. Son, S. B. Sim, Korea Pat. 2011-0009188(2011).

9. Walter Fung, "Coated and Laminated Textiles", Woodhead, Cambridge, pp.83-106, 2002.

10. J. H. Yoo, I. R. Park, J. Kim, H. S. Ahn, S. H. Van and P. G. Lee, Calculations on the Interactions between Main and Jib Sails, J. of the Society of Naval Architects of Korea, 42(1), 1-10(2005).

11. P. K. Lee, H. T. Kim and J. H. Yoo, Numerical Analysis of Blockage Effect on Aerodynamic Force for Yacht Sails in Wind Tunnel Experiment, J. of the Society of Naval Architects of Korea, 43(4), 431-439(2006).

12. J. H. Yoo and H. S. Ahn, Evaluation of Yacht Sails Performance by CFD and Experiments, J. of the Korean Society of Marine Engineering, 30(1), 125-133(2006).

13. J. K. Kim, "Polyurethane : PU Science \& Technology", The Polyurethane Society of Korea, pp.20 $-31,2006$.

14. D. Randall and S. Lee, "The Polyurethane Book", John Wiley \& Sons, Ltd, pp.63-88, 2002. 